\title{
Sturen met Zorg
}

Citation for published version (APA):

de Jong, J. (2020). Sturen met Zorg. Maastricht University. https://doi.org/10.26481/spe.20200306jj

Document status and date:

Published: 06/03/2020

DOI:

10.26481/spe.20200306jj

Document Version:

Publisher's PDF, also known as Version of record

\section{Please check the document version of this publication:}

- A submitted manuscript is the version of the article upon submission and before peer-review. There can be important differences between the submitted version and the official published version of record.

People interested in the research are advised to contact the author for the final version of the publication, or visit the DOI to the publisher's website.

- The final author version and the galley proof are versions of the publication after peer review.

- The final published version features the final layout of the paper including the volume, issue and page numbers.

Link to publication

\footnotetext{
General rights rights.

- You may freely distribute the URL identifying the publication in the public portal. please follow below link for the End User Agreement:

www.umlib.nl/taverne-license

Take down policy

If you believe that this document breaches copyright please contact us at:

repository@maastrichtuniversity.nl

providing details and we will investigate your claim.
}

Copyright and moral rights for the publications made accessible in the public portal are retained by the authors and/or other copyright owners and it is a condition of accessing publications that users recognise and abide by the legal requirements associated with these

- Users may download and print one copy of any publication from the public portal for the purpose of private study or research.

- You may not further distribute the material or use it for any profit-making activity or commercial gain

If the publication is distributed under the terms of Article $25 \mathrm{fa}$ of the Dutch Copyright Act, indicated by the "Taverne" license above, 
Prof. dr. Judith D. de Jong

Faculty of Health, Medicine and Life Sciences

\section{Sturen met zorg}




\section{Sturen met zorg}

Prof. dr. Judith D. de Jong

Rede uitgesproken bij de aanvaarding van het ambt van bijzonder Hoogleraar Zorgstelsel en Sturing aan de Faculteit Health, Medicine and Life Sciences van Maastricht University, vrijdag 6 maart 2020 

Meneer de pro-rector, geachte aanwezigen,

Sinds 1 januari 2019 worden een aantal geneesmiddelen niet meer vergoed vanuit de basisverzekering. Eén van die middelen is vitamine D. Als reden geeft het ministerie van VWS: "De zorgverzekering moet voor alle Nederlanders betaalbaar blijven. Daarom zijn alleen behandelingen en medicijnen verzekerd die een patiënt zelf niet kan betalen. Omdat de gemiddelde kosten voor paracetamol, vitamine $D$ en calcium niet erg hoog zijn, heeft het kabinet deze medicijnen uit het basispakket gehaald. Daarnaast kunt u deze medicijnen zonder recept makkelijk kopen bij de apotheek, drogist of via internet." Het onderzoek naar het effect van de maatregel loopt nog, maar Vektis heeft al wel cijfers laten zien over wat er met vitamine $D$ is gebeurd in het eerste jaar ${ }^{1}$. In plaats van een bezuiniging op de kosten voor zorg vanuit de basisverzekering heeft de maatregel geleid tot een verhoging van de kosten. Bij een aantal patiënten blijkt dat zij nu een andere dosering krijgen voorgeschreven, die wel vergoed wordt vanuit de basisverzekering, maar hogere kosten met zich meebrengt. Er is sprake van substitutie, dit betekent dat het ene middel is vervangen door het andere, en dit kost meer dan dat de maatregel oplevert.

Waarom vertel ik $\mathrm{u}$ dit? Het is een voorbeeld waarin de overheid door middel van beleid probeert te sturen op het verlagen van de collectieve kosten. Met dit voorbeeld wil ik laten zien dat beleid in de praktijk niet altijd werkt zoals de bedoeling was. In het voorbeeld is sprake van een onbedoeld gevolg van beleid: er worden meer kosten gemaakt in plaats van minder. Het beleid heeft in dit geval dus zelfs het tegengestelde effect van wat de bedoeling was. Het laat meteen zien waarom het zo belangrijk is om de gevolgen te evalueren. Het voorbeeld roept ook vragen op. Wat is hier aan de hand? Krijgen mensen gepaste zorg? Hoe zit het met de toegankelijkheid van zorg? En hoe houden we de zorg voor iedereen betaalbaar? Allemaal vragen waar ik graag onderzoek naar doe. Het zijn vragen die gaan over de manier waarop het zorgstelsel is ingericht op het macroniveau, en hoe dit via de uitvoering door organisaties zoals zorgverzekeraars, ziekenhuizen en huisartspraktijken op mesoniveau leidt tot gedrag van verschillende actoren zoals zorgverleners en patiënten, al dan niet in interactie met elkaar, op microniveau. Op geaggregeerd niveau leidt dit gedrag tot patronen van zorggebruik samenhangend met toegankelijkheid, kosten en kwaliteit. De manier waarop het zorgstelsel is ingericht met wetgeving en beleid heeft, zoals ook het voorbeeld laat zien, niet altijd de bedoelde gevolgen. Hoe komt dit? Deze vraag, naar de werking van beleid in de praktijk en dan vooral hoe het komt dat bedoelde gevolgen niet en onbedoelde gevolgen wel optreden, is onderdeel van mijn leerstoel.

De manier waarop door middel van wetgeving en beleid vorm wordt gegeven aan ons zorgstelsel is gebaseerd op beleidsideeën over de manier waarop toegankelijkheid, kwaliteit, en betaalbaarheid op langere termijn gehandhaafd en bevorderd kunnen worden. Deze ideeën zijn feilbaar. Het is daarom belangrijk om zicht te hebben op beleid, veranderingen in beleid en de bedoelde en onbedoelde gevolgen van dat beleid. Evaluatie van beleid is cruciaal, omdat dat de mogelijkheid biedt om te achterhalen of het beleid de beoogde werking heeft, of bijsturing gewenst is en waarop die bijsturing betrekking zou moeten hebben. Ik lever daar met mijn onderzoek graag een bijdrage aan door inzicht

\footnotetext{
${ }^{1}$ https://www.vektis.nl/actueel/kosten-vitamine-d-preparaten-stijgen-in-2019-met-5-miljoen
} 
te geven in hoe beleid uitpakt in de praktijk. Het gaat daarbij zowel om een analyse vooraf, als het beschrijven van wat er gebeurt en om het verklaren ervan. In mijn rede wil ik vooral ingaan op de totstandkoming van bedoelde en onbedoelde gevolgen van beleid. Het verschijnsel van onbedoelde gevolgen is een van de centrale thema's in de sociale wetenschappen. Maar voordat ik hier verder op inga wil ik eerst de context neerzetten. Ik begin daarom met sturing in ons zorgstelsel.

\section{Sturing in het zorgstelsel}

Hoewel het Nederlandse zorgstelsel al jaren goed scoort op verschillende ranglijsten waarin de kwaliteit van zorg in verschillende landen vergeleken wordt, is er zowel in de media als in de politiek voortdurend debat over de zorg. De Nederlandse gezondheidszorg ziet zich geplaatst voor een aantal uitdagingen die op langere termijn bepalend zijn voor de toegankelijkheid, kwaliteit en houdbaarheid van de gezondheidszorg. De zorgvraag neemt toe en verandert van karakter, door ontwikkelingen zoals een toename van het aantal chronisch zieken en vergrijzing, maar ook door technologische ontwikkelingen. Daarnaast vraagt de gezondheidszorg meer personeel dan in de toekomst waarschijnlijk beschikbaar zal zijn. Een belangrijk vraagstuk is daarom hoe efficiënt gebruik gemaakt kan worden van de beperkte middelen in de gezondheidszorg. Dit is een vraagstuk dat aan de orde is bij de inrichting van het zorgstelsel. Door de jaren heen zien we daarbij verschuivingen in de focus en de waarden die centraal staan in het zorgstelsel en daarmee samenhangend in de manier waarop gestuurd wordt. De mate waarin sprake is van sturing door de overheid is hier een voorbeeld van. Een belangrijke verschuiving in ideeën over sturing in de curatieve zorg vond plaats vanaf het midden van de jaren '80. Er was sprake van sterke aanbodsturing waarbij de overheid zich vooral richtte op kostenbeheersing met behoud van toegankelijkheid (Van de Ven, 2015). De kostenbeheersing was succesvol, maar de prijs was onder meer dat er wachtlijsten ontstonden, dat er verschraling van de zorg was en een gebrek aan innovatie. De regulering moest steeds gedetailleerder worden om ongewenste gevolgen te voorkomen. De problemen in het zorgstelsel zouden voortkomen uit het feit dat de gezondheidszorg sterk vanuit het aanbod werd gestuurd, en uit het feit dat het verzekeringsstelsel verschillende compartimenten kende met binnen en tussen de compartimenten financiële, organisatorische en bestuurlijke schotten en verschillen in uitvoeringsstructuur. Er waren nauwelijks prikkels tot doelmatigheid in het stelsel (Van de Ven, 2015). Groeiende consensus dat gedetailleerde overheidsregulering niet de oplossing was, was een opmaat naar een nieuwe fase van overheidsregulering gericht op het bevorderen van doelmatigheid met behoud van toegankelijkheid en kostenbeheersing. Daarbij moeten de gesignaleerde problemen worden gezien tegen de achtergrond van een aantal ontwikkelingen die bepaalde waarden in gevaar brengen of accentueren. Dit betreft een stijgende zorgvraag en stijgende kosten van de zorg die de bestendigheid van het systeem in gevaar brengen en individualisering en toegenomen welvaart die zouden maken dat mensen meer waarde hechten aan keuzevrijheid in de gezondheidszorg. Het gedachtegoed van marktwerking heeft in het zorgstelsel steeds meer voet aan de grond gekregen (De Jong, Van Twist en Chin-A-Fat, 2016). In de jaren ' 80 ontstond het idee dat gereguleerde marktwerking een oplossing kan bieden voor de problemen in het zorgstelsel. In 1987 verscheen het rapport van de commissie Dekker waarin werd beargumenteerd dat marktwerking en concurrentie de doelmatigheid vergroten. Vanaf de jaren ' 90 zijn geleidelijk aan hervormingen doorgevoerd om door middel van marktwerking de overgang van aanbodsturing naar vraagsturing in het zorgstelsel te maken (Van de Ven en Schut, 2008). Een langdurig proces waarin steeds kleine stapjes zijn gezet die het uiteindelijk mogelijk maakten dat de Zorgverzekeringswet werd geïntroduceerd. Er heeft daarbij een verandering 
plaatsgevonden in de ideeën over de manier waarop in het zorgstelsel het beste gestuurd kan worden. Waar het paradigma van aanbodsturing verwijst naar een systeem waarin de overheid een dominante functie vervult in de sturing in het stelsel, biedt het paradigma van vraagsturing veel meer ruimte voor keuzevrijheid, marktwerking en ondernemerschap (Maarse, 2011). In het paradigma van vraagsturing beperkt de rol van de overheid zich tot het stellen van algemene kaders.

Het Nederlandse zorgstelsel is gebaseerd op een aantal principes: toegang tot zorg voor iedereen, ook financieel, solidariteit via een voor iedereen verplichte en toegankelijke zorgverzekering, en goede kwaliteit van zorg. Deze principes worden bewaakt door de overheid. In een aantal stelselwetten wordt het zorgstelsel in Nederland geregeld: de Zorgverzekeringswet (Zvw), de Wet langdurige zorg (Wlz), de Wet maatschappelijke ondersteuning (Wmo) en de Jeugdwet ${ }^{2}$. Voor de uitvoering van de Zorgverzekeringswet (cure) en de Wet langdurige zorg (care) wordt het grootste gedeelte van het budget dat in Nederland beschikbaar is voor zorg gebruikt. Ik richt mij in het vervolg van deze rede vooral op het zorgstelsel voor zover dat onder de Zorgverzekeringswet valt. De Zorgverzekeringswet is op 1 januari 2006 in werking getreden, waarmee een grote stap is gezet in de hervorming van het stelsel. Met de invoering van de Zorgverzekeringswet werd een stelsel ingevoerd van gereguleerde marktwerking. Er is sprake van gereguleerde marktwerking om een aantal ongewenste effecten van marktwerking te voorkomen: er zijn spelregels vastgesteld door de overheid, de publieke randvoorwaarden die het sociale karakter van de verzekering moeten borgen ${ }^{3}$. Denk daarbij bijvoorbeeld aan de verplichting om een basisverzekering af te sluiten en de verplichting voor zorgverzekeraars om iedereen voor de basisverzekering te accepteren tegen dezelfde nominale premie. De overheid blijft verantwoordelijk voor de kwaliteit, toegankelijkheid en betaalbaarheid van zorg. Het zorgverzekeringsstelsel is gebaseerd op solidariteit; via de premie voor het basispakket draagt iedereen bij aan de zorgkosten van zowel zichzelf als van anderen (Maarse 2011; RMO, 2013).

Een belangrijke rol is weggelegd voor zorgverzekeraars ${ }^{4}$. Zij hebben de rol van zorginkoper gekregen, en hebben daarmee eigenlijk de regierol gekregen die eerder bij de overheid lag. Waar in het oude stelsel de overheid de prijzen en volumes van zorg bepaalde, is het nu de bedoeling dat zorgverzekeraars met zorgaanbieders onderhandelen over de prijs, het volume en de kwaliteit van de zorg. Ook van verzekerden wordt iets verwacht: het actief kiezen van een zorgverzekeraar en van

\footnotetext{
${ }^{2}$ Daarnaast is de Wet marktordening gezondheidszorg (Wmg) van belang. De Wmg regelt de ontwikkeling, ordening en het toezicht op de markten voor gezondheidszorg.

${ }^{3}$ Er geldt een plicht om een basisverzekering af te sluiten, maar iedereen mag zelf kiezen bij welke zorgverzekeraar deze verzekering wordt afgesloten; Zorgverzekeraars zijn verplicht om iedereen voor de basisverzekering te accepteren, ongeacht hun gezondheidstoestand; Er geldt een verbod op premiedifferentiatie. De premie van een aangeboden polis is gelijk voor iedere verzekerde, ongeacht zijn gezondheidssituatie, leeftijd of achtergrond; Zorgverzekeraars hebben een zorgplicht: zij moeten garanderen dat de zorg die in het basispakket zit beschikbaar is voor al hun verzekerden; De inhoud van de basisverzekering is wettelijk bepaald.

${ }^{4}$ In het stelsel zijn verschillende actoren actief: zorgverzekeraars, zorgaanbieders en verzekerden/ patiënten. Zij komen elkaar tegen op de drie markten die zijn ontstaan: de zorgverzekeringsmarkt, de zorginkoopmarkt en de zorgaanbiedersmarkt. Op elk van die markten treffen twee actoren elkaar: zorgverzekeraars en verzekerden op de zorgverzekeringsmarkt, zorgverzekeraars en zorgaanbieders op de zorginkoopmarkt, en patiënten en zorgaanbieders op de zorgaanbiedersmarkt. De markten staan niet los van elkaar: keuzes van verzekerden op de zorgverzekeringsmarkt, waar zij hun polis kiezen, zijn van invloed op de keuzevrijheid die zij hebben op de zorgaanbiedersmarkt waar ze als patiënt een zorgaanbieder kiezen. Het contracteerbeleid van zorgverzekeraars op de zorginkoopmarkt bepaalt wat zij aanbieden in de polissen op de zorgverzekeringsmarkt.
} 
zorgverleners is een van de pijlers in het stelsel. Van zorgaanbieders wordt verwacht dat zij patiëntgericht werken en doelmatige zorg leveren. Doelmatigheidsprikkels zijn van belang om de zorg betaalbaar te houden, maar betaalbaarheid is niet het enige beleidsdoel.

Doelmatigheidsprikkels mogen niet ten koste gaan van kwaliteit en toegankelijkheid. Het is daarom belangrijk dat er balans is in het stelsel. Er moeten tegenwichten zijn die er voor zorgen dat als er stevig wordt ingegrepen op de prijs, de kwaliteit en toegankelijkheid niet in het geding komen (Pomp, Mot en Douven, 2006). In het huidige stelsel zouden de verschillende actoren, zorgverzekeraars, zorgaanbieders, verzekerden en patiënten voor die balans moeten zorgen. De bedoeling is dat er zo efficiënt mogelijk gebruik wordt gemaakt van de beperkte middelen die er zijn in de gezondheidszorg.

Ondanks alle goede bedoelingen die er zijn bij de invoering van wet- en regelgeving pakt beleid niet altijd uit zoals het bedoeld is. Er kunnen onbedoelde en ongewenste effecten optreden. Ik ga daarom nu in op het verklaren van de gevolgen van beleid.

\section{Macro- micro- macro model}

Voor het verklaren van de gevolgen van beleid volg ik de aanpak van de sociologen Boudon en Coleman en de filosoof Elster, zoals toegepast in het boek van De Graaf en Wiertz (De Graaf en Wiertz, 2019). Zij zien elk maatschappelijk fenomeen, het macroniveau, als gevolg van gedrag en interacties op individueel niveau, het microniveau. De kern van de verklaring is het gedrag van actoren op het microniveau, maar we moeten dit gedrag wel begrijpen binnen de context van het macroniveau. Omstandigheden op het macroniveau, zoals de Zorgverzekeringswet, beïnvloeden de condities waaronder actoren op het microniveau handelen. Gegeven deze condities op het microniveau, en de doelen en voorkeuren van actoren, vertonen actoren bepaald gedrag. Dit resulteert in uitkomsten op het microniveau. Geaggregeerd leiden deze microniveau uitkomsten tot macroniveau uitkomsten. Kort gezegd: het gedrag van actoren in het zorgstelsel, zorgverzekeraars, zorgaanbieders, verzekerden en patiënten wordt beïnvloed door het beleid van de overheid, de Zorgverzekeringswet, en hoe zij gegeven dit beleid hun doelen kunnen bereiken. Het gedrag van deze actoren gezamenlijk bepaalt de effecten van de Zorgverzekeringswet.

\section{Macro- micro- macro verklaringen}

Om effecten op macroniveau te kunnen verklaren, moeten we dus kijken naar gedrag op microniveau. Sociale mechanismen zijn hierbij relevant. Het gaat er dan om hoe factoren op het macroniveau het gedrag van individuele actoren beïnvloeden, hoe individuele actoren op het microniveau interacteren en hoe het gedrag van veel individuele actoren optelt tot effecten en leidt tot veranderingen op macroniveau. Er kunnen drie sociale mechanismen worden onderscheiden: situationele, actievormende en transformatie mechanismen (Hedström en Swedberg, 1998). Bij situationele mechanismen gaat het erom dat individuele actoren ingebed zijn in een macroniveau context, bijvoorbeeld een land of een mesoniveau context zoals een zorgverzekeraar, ziekenhuis, praktijk of netwerk. Deze context is van invloed op het handelen van de individuele actoren. Een subgroep van situationele mechanismen wordt gevormd door de institutionele mechanismen. Een van de centrale uitgangspunten van institutionele theorie is dat instituties worden gevormd door regels, procedures, normen, waarden en gewoonten (Scott, 2001). Het regulatieve mechanisme heeft betrekking op wet- en regelgeving, het gaat om de regels van het spel. Deze worden 
bijvoorbeeld bepaald in de Zorgverzekeringswet, maar ook in contracten. Het zijn de formele regels. Bij het normatieve mechanisme gaat het om waarden en normen, wat vinden we belangrijk en hoe moeten dingen gaan. Ze zijn informeel, maar wel moreel verplichtend. Bij het cultureel-cognitieve mechanisme gaat het om gedeelde referentiekaders; denkbeelden, conventies en gewoonten. Ze worden als vanzelfsprekend gevolgd. Normen, waarden en gewoonten geven structuur en orde binnen instituties zoals organisaties. Ze kunnen verschillen tussen organisaties, worden niet altijd bewust ervaren, maar als vanzelfsprekend gezien. Dat maakt ze lastig te veranderen.

Op het microniveau spelen actievormende mechanismen, waarbij het gaat over de manier waarop individuen tot beslissingen komen. Hierbij spelen individuele voorkeuren, overtuigingen en mogelijkheden een rol. Om maar weer even terug te komen op de vitamine D; een arts kan bijvoorbeeld veronderstellen dat een patiënt vitamine D niet zelf gaat kopen, dat het niet kopen en dus niet gebruiken schadelijk is voor zijn of haar gezondheid en dat het daarom beter is om een dosering voor te schrijven die wel wordt vergoed. Interessant in dit kader is ook dat het Nederlands Huisartsen Genootschap in reactie op het niet meer vergoeden van vitamine $D$, huisartsen adviseert om bij medische noodzaak patiënten over te zetten op een dosering die wel vergoed wordt ${ }^{5}$. Ook apothekers zouden een rol spelen kunnen spelen in het omzetten van patiënten op een dosering die wel vergoed wordt.

De derde groep mechanismen die van belang is voor het verklaren van macroniveau uitkomsten bestaat uit transformatiemechanismen. Deze mechanismen zijn van belang om te verklaren hoe het individuele gedrag op het microniveau gezamenlijk leidt tot uitkomsten op het macroniveau. Het zijn externe gevolgen van individueel gedrag: gevolgen die door het individu niet worden meegenomen bij een beslissing, maar die wel gevolgen hebben voor anderen en de maatschappij als geheel (De Graaf en Wiertz, 2019). Om een voorbeeld te geven: het idee achter gereguleerde concurrentie is dat doordat individuele verzekerden uit eigen belang kiezen voor de best passende zorgverzekering er signalen aan zorgverzekeraars worden gegeven met betrekking tot de prijs en de kwaliteit van de zorg. Het is in het belang van een zorgverzekeraar om verzekerden aan te trekken en te behouden en daarom zal deze zich inspannen voor een goede prijs- kwaliteit verhouding. Het gevolg op macroniveau is dan dat zorgkosten zo laag mogelijk zijn bij een goede kwaliteit. Het individuele handelen vanuit eigen belang heeft dan dus op macroniveau gevolgen waar iedereen van profiteert. In de praktijk zien we wel een effect op de prijs, maar niet op de kwaliteit.

\section{Bronnen van onbedoelde gevolgen}

In het hele proces van de totstandkoming van gevolgen op macroniveau bevinden zich bronnen van onbedoelde gevolgen. Ik noem er vier (Delnoij e.a. 1998; Boudon, 1982; Groenewegen, De Jong en Kerssens, 2002).

\section{Verschuiving van de aantrekkelijkheid of kosten van opties}

De eerste betreft een verschuiving van de aantrekkelijkheid of kosten van opties. In het voorbeeld dat ik aan het begin van mijn rede gaf, zagen we zo'n verschuiving. Als gevolg van het niet meer vergoeden van vitamine $D$ vanuit de basisverzekering wordt het voor een individu aantrekkelijk om te kiezen voor een variant die wel vergoed wordt, maar duurder is. En kennelijk zetten zorgverleners,

\footnotetext{
${ }^{5}$ https://www.nhg.org/actueel/nieuws/paracetamol-vitamines-en-mineralen-niet-langer-vergoed
} 
als agent van hun patiënten, die patiënten om op het duurdere middel. Het onbedoelde en ongewenste gevolg is dat de collectieve kosten stijgen. Een individuele patiënt kan voordeel hebben bij het krijgen van het duurdere middel, hij of zij hoeft dan de kosten niet uit eigen zak te betalen, maar dit voordeel voor een enkel individu leidt tot een nadeel voor alle verzekerden. Zij moeten namelijk de hogere kosten opbrengen. Vektis rekende uit dat de kostenstijging 5 miljoen euro in 2019 bedraagt $^{6}$. Overigens zou het niet meer gebruiken van vitamine $\mathrm{D}$ ook tot collectieve ongewenste effecten kunnen leiden, als mensen daardoor later duurdere zorg nodig hebben.

Onderlinge afhankelijkheid

Een andere bron van onbedoelde gevolgen is gevolg van onderlinge afhankelijkheid. Het gaat bijvoorbeeld om inspanningen die geleverd worden door een zorgverzekeraar, waarvan niet alleen de eigen verzekerden profiteren. Denk daarbij aan kwaliteitsafspraken die een zorgverzekeraar kan maken met zorgaanbieders, niet alleen de eigen verzekerden maar ook verzekerden van andere zorgverzekeraars profiteren hiervan. Er vindt dan free-riding plaats ${ }^{7}$. Een risico is dat verzekeraars daardoor niet investeren in kwaliteitsafspraken met zorgaanbieders.

\section{Onjuiste inschatting van het gedrag van actoren}

Ook een onjuiste inschatting van het gedrag van actoren kan leiden tot onbedoelde gevolgen. Neem het verplichte eigen risico. Het verplicht eigen risico is onder andere bedoeld om verzekerden meer bewust te maken van de kosten van hun zorggebruik. Doordat verzekerden geconfronteerd worden met kosten als zij zorg gebruiken, zouden zij de kosten mee gaan wegen bij de beslissing om zorg te gebruiken. Op deze manier zou onnodig en oneigenlijk gebruik van medische voorzieningen worden beperkt (Van der Geest, 2008; Westerhout en Folmer, 2007). De overheid veronderstelt dat eigen betalingen in de gezondheidszorg een remmend effect op het zorggebruik hebben en dit zou leiden tot lagere collectieve kosten. Onbedoeld effect kan echter zijn dat verzekerden ook zorg die zij wél nodig hebben vermijden. Op termijn kan zo'n beslissing leiden tot hogere kosten, omdat iemand dan zieker is en een duurdere behandeling nodig heeft. Dit geldt niet alleen voor het eigen risico, maar voor alle eigen betalingen in de zorg. Ons onderzoek naar zorgmijden laat zien dat ongeveer $9 \%$ van zorg afziet vanwege de kosten (Meijer e.a., 2020). Ook volgt ongeveer een vijfde een verwijzing van de huisarts niet op (Van Esch e.a., 2015). We weten alleen niet wat daar de reden voor is.

\section{Verschillen in decentrale uitvoering van het beleid}

Een vierde bron betreft verschillen in decentrale uitvoering van beleid. Een decentrale uitvoering van beleid kan leiden tot onbedoelde gevolgen, bijvoorbeeld door doelverschuiving. De Zorgverzekeringswet is door de overheid ingevoerd, maar wordt decentraal uitgevoerd. Zorgverzekeraars hebben de rol van zorginkoper gekregen. Idee is dat ze inkopen op zowel prijs en

\footnotetext{
${ }^{6} \mathrm{https}: /$ www.vektis.nl/actueel/kosten-vitamine-d-preparaten-stijgen-in-2019-met-5-miljoen

${ }^{7}$ Het zijn situaties die kunnen ontstaan in een stelsel met concurrerende zorgverzekeraars. Bedoeling is dat de concurrentie op zowel prijs als kwaliteit plaatsvindt. Onbedoeld gevolg kan zijn dat zorgverzekeraars niet gaan investeren in kwaliteitsafspraken. In ons zorgstelsel zien we dat ook de landelijke verzekeraars regionale zwaartepunten hebben. Ze zijn vooral in deze gebieden actief, waar ze ook het meest kunnen profiteren van hun inspanningen. Een risico kan ontstaan wanneer er alleen landelijk opererende zorgverzekeraars zijn, zonder regionale zwaartepunten, dus elk met verzekerden verspreid over het hele land. Dan kan een patstelling ontstaan waarbij geen van de verzekeraars investeert in kwaliteitsafspraken met zorgaanbieders.
} 
volume als kwaliteit. Bij gebrek aan informatie over kwaliteit kan dit verschuiven naar inkoop vooral op prijs en volume. Dit kan negatieve onbedoelde effecten voor de kwaliteit van zorg hebben.

\section{Beleid in de praktijk}

Diverse onderzoeken laten zien dat de gereguleerde concurrentie in de zorg niet helemaal uitpakt zoals de bedoeling was. Als oorzaken voor het niet optreden van bedoelde effecten wordt door Rotterdamse economen een aantal falende randvoorwaarden genoemd (Van de Ven, 2015; Varkevisser, 2019; Van Kleef e.a. 2014). Het gaat dan bijvoorbeeld om de gebrekkige transparantie over kwaliteit van zorg. Het ontbreken van informatie over de kwaliteit van zorg kan in een stelsel met concurrentie uiteindelijk leiden tot een afname van de kwaliteit van zorg. De Rotterdamse economen stellen dat "gereguleerde concurrentie in de zorg kan alleen tot kwalitatief goede, doelmatige en toegankelijke zorg leiden indien aan belangrijke noodzakelijke voorwaarden is voldaan" (Van de Ven, 2015). Deze randvoorwaarden hebben betrekking op de regulatieve aspecten van instituties. Voor de inrichting van het stelsel is een aantal instrumenten ingezet om zo goed mogelijk aan de voorwaarden te voldoen. Maar er is meer dan dat. Naast deze regulatieve aspecten die van invloed zijn op het gedrag van actoren, spelen ook normatieve en cultureel-cognitieve aspecten van instituties een rol. En deze beïnvloeden elkaar onderling. Ik geef het voorbeeld van zorgsturing door zorgverzekeraars en van keuzes van verzekerden.

\section{Zorgsturing door zorgverzekeraars}

In het stelsel van gereguleerde marktwerking is een belangrijke rol weggelegd voor zorgverzekeraars. Zij moeten namens hun verzekerden zorg inkopen bij zorgaanbieders en daarbij onderhandelen over de prijs en kwaliteit. Zorgverzekeraars treden op als vertegenwoordigers van hun verzekerden. Voor hun onderhandelingspositie ten opzichte van zorgaanbieders is het belangrijk dat zij invloed hebben op de keuzes die verzekerden maken (Varkevisser, Polman en Van der Geest, 2006). De mate waarin zij daarin slagen bepaalt hun inkoopmacht ten opzichte van die zorgaanbieders en daarmee de mate waarin zij gunstige contractafspraken met zorgaanbieders kunnen maken, zoals een lagere prijs en betere kwaliteit. Een van de instrumenten ${ }^{8}$ die zorgverzekeraars hiervoor hebben is selectief contracteren. Dat betekent dat zij niet met elke zorgaanbieder een contract hoeven af te sluiten. Selectieve zorginkoop door zorgverzekeraars is nauwelijks van de grond gekomen. Rolverwachtingen en vertrouwen zijn hierop van invloed. Ik zal dat toelichten.

In wet- en regelgeving is vastgelegd dat zorgverzekeraars de rol van zorginkoper hebben en dat zij selectief mogen contracteren. Dit wil echter nog niet zeggen dat zij deze rol ook uit kunnen voeren. Andere actoren moeten deze nieuwe rol accepteren. Doen zij dit niet, dan kan dit de speelruimte van zorgverzekeraars ernstig beperken. De normatieve en de cultureel-cognitieve aspecten van instituties kunnen de regulatieve institutie tegenwerken. Daarnaast is de regulatieve institutie van invloed op de andere instituties. Zo kan door de invoering van gereguleerde marktwerking het vertrouwen van zorgaanbieders in zorgverzekeraars afnemen ${ }^{9}$ (Groenewegen, Hansen en De Jong, 2019). Een laag vertrouwen maakt contractonderhandelingen lastiger. Ook als we naar de relatie zorgverzekeraarverzekerden kijken zien we een vertrouwensprobleem (Boonen en Schut 2009; Bes, Wendel en De Jong, 2012). Ons onderzoek laat zien dat er vooral weinig vertrouwen van verzekerden in

\footnotetext{
${ }^{8}$ Naast selectief contracteren kunnen er ook voorkeursaanbieders worden aangewezen.

${ }^{9}$ We zien een afname bij de meeste zorgaanbieders, maar deze is alleen significant voor fysiotherapeuten.
} 
zorgverzekeraars is als het gaat om het geven van advies aan patiënten bij het kiezen van een behandeling en als het gaat om het bepalen welke behandelingen zorgaanbieders mogen geven (Hoefman, Brabers en De Jong, 2015). Slechts zo'n 15\% vindt dit taken van een zorgverzekeraar en $10 \%$ heeft vertrouwen in de uitvoering ervan. Verzekerden zien voor zorgverzekeraars vooral taken op het gebied van informeren over de prijs en beschikbaarheid van zorg. Dit past bij de rol die zorgverzekeraars hadden in het oude stelsel. Gevolg van deze rolopvatting en het lage vertrouwen van verzekerden in zorgverzekeraars is dat het beperken van de keuzevrijheid, door selectief contracteren op weerstand van verzekerden kan stuiten. Daar komt nog bij dat ruim twee derde (69\%) van de verzekerden denkt dat zorgverzekeraars geld besparen belangrijker vinden dan de benodigde zorg in kopen (Hoefman, Brabers en De Jong, 2015). Deze beeldvorming die verzekerden hebben over zorgverzekeraars vanwege hun rol als zorginkoper is van invloed op het vertrouwen dat zij hebben in zorgverzekeraars (zie invloed van culture beliefs in Van der Schee, 2016). Onze barometer vertrouwen laat zien dat het vertrouwen van verzekerden in zorgaanbieders vele malen hoger is dan het vertrouwen in zorgverzekeraars. Verzekerden zullen dus eerder overstappen van zorgverzekeraar zodat zij nog wel naar hun eigen zorgaanbieder kunnen dan dat zij wisselen van zorgaanbieder en bij hun zorgverzekeraar blijven. Dit maakt dat selectief contracteren voor zorgverzekeraars op eieren lopen is.

De ruimte die zorgverzekeraars gekregen hebben vanuit het beleid is overigens ook beperkt vanwege het zogenaamde hinderpaalcriterium. Dit komt er feitelijk op neer dat zorgverzekeraars ook de kosten van niet gecontracteerde zorgaanbieders voor zo'n groot deel moeten vergoeden dat het de keuzevrijheid van patiënten niet in de weg staat. En dat betekent voor zorgaanbieders dat patiënten wel komen, of er nu een contract is of niet. Dit beperkt de inkoopmacht van zorgverzekeraars ten opzichte van zorgaanbieders. Er is geprobeerd om het hinderpaalcriterium ongedaan te maken via een wijziging van artikel 13 van de Zorgverzekeringswet. Dit is echter niet gelukt vanwege maatschappelijke en politieke weerstand. Zorgaanbieders hebben hier een belangrijke rol in gespeeld door het afschaffen van het hinderpaalcriterium te framen als een beperking van de vrije artsenkeuze. En dat is kennelijk een waarde waar nog niet aan getornd mag worden.

\section{Keuzes van verzekerden en patiënten}

Het tweede voorbeeld gaat over keuzes van verzekerden en patiënten. Om het stelsel te laten werken zoals bedoeld zijn kritische, mobiele verzekerden essentieel. Doordat verzekerden de vrijheid hebben om jaarlijks van verzekeraar te wisselen ontstaat er een druk op verzekeraars om in hun aanbod van polissen rekening te houden met de wensen van verzekerden, wat betreft prijs, service en kwaliteit van de ingekochte zorg. Om dit te laten werken zoals bedoeld is het wisselen van zorgverzekeraar van belang ${ }^{10}$. Als verzekerden niet wisselen, dan krijgen verzekeraars geen prikkels om de premie laag en de kwaliteit goed te houden. In de praktijk zien we dat een deel van de verzekerden inderdaad van zorgverzekeraar wisselt. In het Consumentenpanel Gezondheidszorg vragen we jaarlijks of mensen zijn gewisseld van zorgverzekeraar en wat hun redenen daarvoor zijn. Elk jaar wisselt ongeveer $10 \%$ van de verzekerden. Deze verzekerden wisselen vooral omdat ze ontevreden zijn over de premie. Kwaliteit van zorg speelt bij de keuze voor een andere zorgverzekeraar nauwelijks een rol. Met het wisselen geven verzekerden dus vooral een prijsprikkel

\footnotetext{
${ }^{10}$ Niet iedereen hoeft te wisselen, de mogelijkheid tot kiezen zal al een zekere druk op de verzekeraars leggen.
} 
af aan zorgverzekeraars. Niet alleen omdat overwegingen met betrekking tot kwaliteit nauwelijks een rol spelen, maar ook omdat het vooral jongeren zijn die wisselen. Zij maken minder gebruik van zorg dan ouderen. Er is dus sprake van concurrentie op prijs, maar van concurrentie op kwaliteit lijkt geen sprake. Dit was echter wel de bedoeling van het stelsel. Verzekerden gedragen zich niet in overeenstemming met de beleidstheorie en hierdoor treden de bedoelde effecten niet op. Daarnaast is er een risico dat er wel onbedoelde en ongewenste effecten optreden. Een risico van uitsluitend prijsconcurrentie is namelijk dat dit uiteindelijk ten koste gaat van de kwaliteit. Om de bedoelde gevolgen te bereiken is beleid ingezet om het voor verzekerden gemakkelijker te maken om te wisselen van zorgverzekeraar, zo is er de acceptatieplicht, mag er gewisseld worden voor de basisverzekering terwijl men de aanvullende verzekering bij een andere zorgverzekeraar houdt en hebben zorgverzekeraar een overstapservice waarbij een verzekerde de oude zorgverzekering niet zelf hoeft op te zeggen. Dit is er allemaal op gericht dat iedereen, ongeacht kenmerken zoals leeftijd of gezondheidstoestand, onbelemmerd kan wisselen van zorgverzekeraar. Toch wisselt maar een beperkte groep verzekerden. Een verklaring zou kunnen liggen in de cultureelcognitieve institutie; verzekerden zijn niet gewend om jaarlijks te wisselen en doen het daarom niet. Ook beeldvorming speelt een rol. Een kleine percentage verzekerden wisselt niet omdat zij administratieve problemen verwachten, of problemen met de acceptatie voor de aanvullende verzekering (Holst, Brabers en De Jong, 2019). Het niet wisselen van zorgverzekeraar kan ook heel rationeel zijn: als andere verzekerden wisselen zorgen zij ervoor dat zorgverzekeraars scherp blijven en de premie laag houden en hoef ik dus niet te wisselen.

Er wordt overigens niet alleen een actieve rol verwacht als het gaat om het kiezen van een zorgverzekering, maar ook als het gaat om het kiezen van een zorgaanbieder. Door actief te kiezen zouden patiënten zorgaanbieders stimuleren tot betere prestaties. Onderzoek van Aafke Victoor laat zien dat de kiezende patiënt die op zoek gaat naar de best passende zorgaanbieder een speld in een hooiberg is (Victoor, 2015). De meeste patiënten volgen het advies van hun huisarts. Ook dit zit ingebakken in een institutionele structuur die zich moeilijk laat veranderen.

En nu kom ik weer terug bij sturing in de zorg. Het is duidelijk dat sturing in de zorg geen lineair proces is. Het is een complex geheel van mechanismen die elkaar kunnen beïnvloeden, zowel positief als negatief. Tegelijkertijd zijn er allerlei ontwikkelingen die het vraagstuk van de inrichting van het zorgstelsel actueel houden. Het gaat dan bijvoorbeeld over de toename van het aantal chronisch zieken, de vergrijzing en personeelstekorten. Er moet worden nagedacht over nieuwe manieren om het zorgstelsel in te richten, om te sturen zodat de zorg ook in de toekomst kwalitatief goed, toegankelijk en betaalbaar is. Hoewel het dominante denken nog steeds uitgaat van gereguleerde marktwerking, is er ook kritiek op bijvoorbeeld de administratieve lasten voor zorgverleners i.v.m. verantwoording en op gebrekkige samenhang in het zorgstelsel. De invoering van gereguleerde marktwerking, met concurrentie, focus op prestatie, kostenreductie en een meer bedrijfsmatige benadering, heeft geleid tot een bepaalde mate van verzakelijking van de zorg (De Jong, Van Twist en Chin-A-Fat, 2016). Daarnaast is er weinig aandacht voor samenwerking, doordat contracten worden afgesloten met specifieke organisaties die afgerekend worden op specifieke prestaties. We zien nu een verschuiving van ideeën over sturing op efficiëntie en effectiviteit naar meer aandacht voor waarde gedreven zorg. Hierbij past de beweging Juiste Zorg Op De Juiste Plek waarbij kwaliteit van leven en het dagelijks functioneren van mensen uitgangspunten zijn voor het organiseren van zorg. Het gaat dan niet meer om een enkele behandeling, maar om samenhangende 
zorg. In dat geval zou inkoop door zorgverzekeraars moeten leiden tot een samenhangend zorgaanbod waarbij de behoeften van patiënten centraal staan. Dit vraagt om flexibele netwerken, die afhankelijk zijn van de zorgvraag. Het lijkt niet eenvoudig om dit te realiseren en in te kopen. De vraag naar hoe we ons zorgstelsel moeten inrichten om aan te sluiten bij de huidige waarden en hoe het stelsel houdbaar blijft zal blijven bestaan. De inrichting van een zorgstelsel is ingewikkeld en vraagt inzicht in sturing om ervoor te zorgen dat bedoelde gevolgen wel en onbedoelde en ongewenste gevolgen niet optreden. Het is een voortdurend sturen en bijsturen, op zoek naar balans in het stelsel.

Mede vanuit de wens om samenhang en samenwerking te bevorderen zien we momenteel steeds meer aandacht voor de regio als eenheid waarbinnen naar oplossingen gezocht moet worden.

Minister De Jonge heeft gesteld dat het geloof in de markt als oplosser voor problemen in de zorg op $z^{\prime} n$ retour is ${ }^{11}$. Nu kunnen daar allerlei kanttekeningen bij geplaatst worden, feit is dat er momenteel veel gesproken wordt over regionalisering. Ook Minister Bruins heeft het over regionale samenwerking, maar wel binnen het huidige stelsel van gereguleerde concurrentie ${ }^{12}$. Er lijkt een brede overeenstemming te ontstaan dat samenwerking belangrijker is dan concurrentie, terwijl die samenwerking moet worden bevorderd binnen een stelsel dat daar niet op is ingericht.

Regionalisering zou een nieuwe strategie ${ }^{13}$ zijn om doelmatiger te gaan werken en de kwaliteit van de zorg te verbeteren. Ook in de hoofdlijnenakkoorden zien we dit terugkomen. Initiatieven om de zorg regionaal te organiseren worden al ontplooid, vooral in de ouderenzorg waar de tekorten het grootst zijn (Bal, Wallenburg en Schuurman, 2019).

Er zijn echter nog veel openstaande vragen, zoals de vraag naar wat de regio eigenlijk is, of dat niet verschilt tussen zorgvormen en hoe de bekostiging zou moeten worden ingericht. Daarnaast blijven meer fundamentele problemen in het zorgstelsel bestaan. Een van die problemen is een gebrek aan vertrouwen tussen de verschillende partijen. We zien dit bij samenwerking tussen de eerste en de tweede lijn (verwijzing kennisvraag substitutie), en we zien het ook naar voren komen in de experimenten die er al gedaan worden met betrekking tot regionale samenwerking (https://www.rivm.nl/proeftuinen-toekomstbestendige-zorg). Dit gebrek aan vertrouwen kan er toe leiden dat de uitvoeringskosten toenemen, of dat de samenwerking niet van de grond komt. Ook blijft het probleem van een gebrek aan kwaliteitsinformatie bestaan en dit heeft het risico in zich dat er vooral naar de prijs wordt gekeken. Daarnaast lijkt de huidige bekostigingsstructuur niet goed te passen bij een regionale samenwerking. De inzet op regionale samenwerking vraagt om aanpassingen in wet- en regelgeving. Bij eerdere aanpassingen in wet- en regelgeving heb ik laten zien dat alleen dat onvoldoende is. Er is ook een omslag nodig op andere aspecten van instituties, zoals normen, waarden en gewoonten. Dat zal weer veel tijd in beslag nemen, en het is de vraag of dat matcht met de termijn waarop er in de politiek resultaten verwacht worden.

Een verandering in wet- en regelgeving is van invloed op de andere aspecten van instituties. Inzet op regionale samenwerking kan waarden in het stelsel zoals keuzevrijheid en solidariteit aantasten. Welke keuze hebben patiënten binnen een regio? En wat betekent de inzet op de regio voor de

\footnotetext{
${ }^{11}$ Algemeen Dagblad. We moeten bij de zorg terug naar het gezond verstand. 1 maart 2019

${ }^{12}$ Kamerbrief 28 januari 2019. Antwoorden op de vragen van het Kamerlid Ploumen (PvdA) over de noodzaak van nationale regie om de zorg betaalbaar te houden (2019Z00076)

${ }^{13}$ Helemaal nieuw is de discussie niet, ook in de jaren 1970/1980 was sprake van regionalisering
} 
bereidheid tot solidariteit in het hele zorgstelsel? Daarnaast zullen er overeenkomsten zijn tussen regio's in problematiek, maar kan het oplossend vermogen verschillen bijvoorbeeld door verschillende uitgangssituaties als het gaat om een cultuur van samenwerking. Dit kan leiden tot regionale variatie in de kwaliteit van de zorg, de toegankelijkheid en de kosten van zorg. Regionale variatie kan acceptabel zijn als dit te maken heeft met verschillen in zorgbehoeften tussen de inwoners, maar hoe voorkomen we variatie die niet acceptabel is?

In mijn leerstoel zal ik mij bezighouden met dergelijke veranderingen in het stelsel, maar ook met de huidige inrichting van het stelsel, en of daarbij de bedoelde effecten wel en onbedoelde effecten niet optreden.

\section{Mijn leerstoel}

En zo kom ik bij het onderdeel van mijn rede waarin ik u ga vertellen over het onderzoek dat ik binnen mijn leerstoel "Zorgstelsel en Sturing" zal doen. Mijn onderzoek richt zich op twee inhoudelijke hoofdthema's:

1. Onderzoek naar de inrichting van het zorgstelsel, veranderingen in het zorgstelsel, de invloed daarvan op het gedrag van actoren en het verklaren van variatie;

2. De bedoelde en onbedoelde effecten van beleid.

Onderzoek naar de inrichting van het zorgstelsel, veranderingen in het zorgstelsel, de invloed daarvan op het gedrag van actoren en het verklaren van variatie

Bij het eerste onderzoeksthema ligt de nadruk op de inrichting van het zorgstelsel en daarmee samenhangend de institutionele structuur. Internationaal onderzoek is binnen dit thema van belang omdat dit mogelijkheden biedt om verschillende beleidsoplossingen met elkaar te vergelijken. Wereldwijd stijgen de kosten van de gezondheidszorg en een steeds groter deel van de collectieve middelen wordt besteed aan de gezondheidszorg. Het inrichten van een houdbaar zorgstelsel dat toegankelijk is en kwalitatief goede zorg biedt is daarmee een van de grootste uitdagingen waar landen voor staan. Dat verschillende landen voor vergelijkbare problemen staan maakt internationaal vergelijkend onderzoek interessant en relevant. Hoewel de effecten van beleid contextafhankelijk zijn, biedt dit wel de mogelijkheid om te leren van andere landen en zicht te krijgen op welke maatregelen effectief zijn in welke context ${ }^{14}$.

Naast het vergelijken van beleidsoplossingen is het van belang om zicht te krijgen op hoe regels, normen, denkbeelden en referentiekaders van invloed zijn op elkaar en hoe dit de effectiviteit van het zorgstelsel beïnvloedt, maar ook hoe dit verandering tot stand kan brengen. Zo kan de aandacht voor keuzevrijheid en de mogelijkheid tot actief kiezen tot onbedoeld effect hebben dat de bereidheid tot solidariteit afneemt. De nadruk op kiezen vanuit wet- en regelgeving kan het referentiekader veranderen en daardoor leiden tot onbedoelde effecten, namelijk dat mensen ook willen kiezen voor welke zorg ze wel en voor welke ze niet betalen. Hierdoor neemt de bereidheid tot solidariteit af. Ook kunnen veranderingen in wet- en regelgeving vertrouwen tussen de verschillende actoren aantasten als bijvoorbeeld niet duidelijk is wat de intenties van actoren zijn. Dit speelt een

\footnotetext{
${ }^{14}$ Zie bijvoorbeeld het To- Reach project: https://to-reach.eu/wp-content/uploads/2019/05/TO-REACH-draft-SRA_May-16-2019_FinalV.pdf
} 
rol als artsen financiële prikkels krijgen om minder zorg te verlenen, patiënten weten dan niet of een bepaalde keuze in hun belang is, of in het belang van een arts. Een afname van het vertrouwen tussen patiënten en artsen kan onder meer therapietrouw negatief beïnvloeden. Ook de toegenomen aandacht voor het transparant maken van uitkomsten van zorg of van de kwaliteit van zorg kan vertrouwen beïnvloeden, zowel negatief als positief. Negatieve boodschappen verlagen het vertrouwen, positieve boodschappen kunnen het vertrouwen verhogen (Van de Schee, 2016). Het monitoren van solidariteit en vertrouwen is daarom van belang, om zo een vinger aan de pols te houden. We doen dit met de barometer vertrouwen en de barometer solidariteit. Onderzoek richt zich daarbij ook op het begrijpen van veranderingen.

Het Nederlandse zorgstelsel kent een hoge mate van solidariteit; gezond betaalt voor ziek en rijk voor arm. Om de solidariteit te behouden is het van belang dat er gepaste zorg wordt verleend. Overen onderbehandeling, en daarmee ongewenste praktijkvariatie, moeten daarbij zoveel mogelijk worden teruggedrongen. Variatie kan voortkomen uit de manier waarop het stelsel is ingericht. Of variatie gewenst of ongewenst is, is lastig aan te geven. Ook is de relatie tussen gepaste zorg en variatie niet helder. Dit maakt dat sturen op het terugdringen van variatie negatieve gevolgen kan hebben. Het is dus noodzakelijk dat er meer inzicht komt in het verklaren van variatie, de relatie met gepaste zorg en hoe de inrichting van het zorgstelsel hierop van invloed is. Ook de toegenomen aandacht voor samen beslissen kan van invloed zijn op praktijkvariatie, zoals Anne Brabers liet zien in haar proefschrift (Brabers, 2018). In samenwerking met collega's van de Universiteit Maastricht, de Hogeschool Utrecht en het Nivel starten we een onderzoek op naar variatie in indicatiestelling in de wijkverpleegkundige zorg. Een ander onderzoek richt zich op variatie in de verloskunde, waar we specifiek naar variatie in het inleiden van bevallingen kijken. Dit onderzoek wordt in samenwerking met Zuyd Hogeschool uitgevoerd. In beide onderzoeken richten we ons op het verklaren van variatie om daarmee aanknopingspunten te vinden om ongewenst variatie terug te dringen.

Voor het begrijpen van de werking van het zorgstelsel is het van belang om inzicht te hebben in het gedrag van actoren, zoals zorgverzekeraars, zorgaanbieders, verzekerden en patiënten. In dat kader doen we bijvoorbeeld onderzoek naar het wisselen van zorgverzekeraar en de redenen die verzekerden hebben om al dan niet te wisselen. Ook onderzoeken we de kennis en vaardigheden die mensen hebben met betrekking tot het zorgstelsel en keuzes die zij maken.

De bedoelde en onbedoelde effecten van beleid

Het tweede thema is verweven met het eerste thema, maar heeft daarbij een focus op de bedoelde en onbedoelde effecten van beleid. Onderzoek met deze focus is van belang, omdat dat de mogelijkheid biedt om te achterhalen of het beleid de beoogde werking heeft, of bijsturing gewenst is en waarop die bijsturing betrekking zou moeten hebben. Interessant hierbij zijn de ontwikkelingen waarbij steeds meer gedecentraliseerd wordt. Het beleid van de landelijke overheid wordt daarbij vertaald door zorgverzekeraars of lokale overheden. Hierdoor kunnen verschillen ontstaan én de mogelijkheid kan ontstaan dat "best practices" worden gedeeld. Andere voorbeelden van onderwerpen waarbij we kijken naar bedoelde en onbedoelde gevolgen zijn: het eigen risico dat wordt vastgesteld door de landelijke overheid met als bedoelde effecten een financieringverschuiving en bewustwording bij mensen dat zorg geld kost en als mogelijk onbedoeld effect het mijden van noodzakelijke zorg. Ook de onbedoelde gevolgen van pakketbeslissingen vallen 
binnen deze onderzoekslijn, waarbij ook de vraag gesteld moet worden wat er nu eigenlijk gebeurt in het beslissingsproces van patiënten en zorgverleners. Verzekerden willen een lage premie, maar als patiënt hebben zij er belang bij dat er zoveel mogelijk vergoed wordt. Het beperken van de zorgkosten is vooral een zorg voor overheid en zorgverzekeraars en minder voor zorgverleners. Dit kan tot gevolg hebben dat er in het beslissingsproces tussen zorgverlener en patiënt beslissingen worden genomen die leiden tot onbedoelde gevolgen voor verzekerden.

Slot

Ik kom aan het einde van mijn rede. Het zorgstelsel in Nederland is goed dat willen we zo houden. We zien een afname van de groei van de uitgaven aan gezondheidszorg ${ }^{15}$ (Van Kemenade, 2019). De solidariteit in het stelsel is met de invoering van de Zorgverzekeringswet toegenomen. Er is veel bereikt. Toch zijn er door allerlei ontwikkelingen veranderingen in het stelsel nodig om het goed te houden. En zijn er onbedoelde en ongewenste effecten van beleid. En daarvoor is bijstelling, afschaffing of vernieuwing van beleid noodzakelijk. Inzicht in de bronnen van onbedoelde gevolgen kan bijdragen aan het verbeteren van beleid. Het geeft inzicht in aangrijpingspunten om beleidsmatig te anticiperen op onbedoelde en ongewenste effecten. Dit inzicht kan helpen om met zorg te sturen. Sturen met zorg moet met zorg worden gedaan. Een zorgstelsel is nooit af, sturing en bijsturing zullen altijd nodig blijven. Het zorgstelsel is daarbij wel gebaat bij een zekere mate van continuïteit, actoren moeten de kans krijgen om nieuwe rollen te kunnen invullen zodat het stelsel kan werken zoals dat bedoeld is.

\footnotetext{
${ }^{15}$ Het is de vraag of dit door de hervormingen komt, of door de landelijke afspraken die tussen verschillende partijen zijn gemaakt.
} 


\section{Dankwoord}

Dan ben ik nu aangekomen bij mijn dankwoord. De Universiteit van Maastricht - in het bijzonder CAPHRI- en het Nivel wil ik bedanken voor het mogelijk maken van deze leerstoel en het in mij gestelde vertrouwen. Peter Groenewegen, Dirk Ruwaard en Nanne de Vries zagen mogelijkheden voor samenwerking op het gebied van zorgstelsel en sturing en hebben zich ingezet voor een leerstoel op dit gebied.

Binnen CAPHRI is de leerstoel ondergebracht binnen de vakgroep Health Services Research onder leiding van Dirk Ruwaard, en het programma Value Based Healthcare onder leiding van Sylvia Evers en Peter Schröder- Bäck. Dirk, jij hebt gezorgd voor mijn introductie binnen de vakgroep en de academische werkplaats duurzame zorg, zodat ik de raakvlakken kon verkennen. Dat er veel raakvlakken zijn bleek ook uit mijn gespreksronde met stakeholders waar jouw naam regelmatig viel. Ik kijk uit naar de verdere samenwerking!

Twintig jaar geleden ben ik bij het Nivel naar binnen gestapt. Ik ben daar na mijn afstuderen gaan werken en er geworden tot de onderzoeker die ik nu ben. Het vertrouwen, de steun, de uitdagingen en de mogelijkheden om mij verder te ontwikkelen hebben mij tot dit punt gebracht. Daarvoor wil ik in het bijzonder Peter Groenewegen bedanken. Peter, jij bent mijn leermeester geweest en hebt mij als onderzoeker het meest gevormd. Ik ben blij dat ik nog steeds bij je binnen kan lopen om van gedachten te wisselen, voor je eerlijk advies, kritisch commentaar of om een boek te lenen.

Daarnaast wil ik mijn huidige leidinggevende Roland Friele bedanken. Roland, je hebt verfrissende ideeën, die aanzetten tot nadenken. Ook Cordula Wagner, directeur van het Nivel, afdelingshoofden, mijn collega programmaleiders en andere collega's wil ik bedanken voor de prettige werkomgeving. Het voert wat ver om iedereen op te noemen, maar twee mensen die er vanaf mijn eerste Nivel dag waren wil ik toch niet onvermeld laten: Wienke Boerma en Liset van Dijk. Wienke, je bent een bijzonder mens. Al zolang ik bij het Nivel werk loop jij regelmatig even bij me langs om te checken hoe het gaat. Het is fijn om zo'n collega te hebben. Liset, als student assistent heb ik voor jouw project enveloppen ingepakt en interviews afgenomen. Mijn eerste stappen in onderzoek. Inmiddels zijn we allebei hoogleraar. Het is ontzettend leuk dat we nog steeds met zo veel plezier samen aan onderzoek kunnen werken.

In de afgelopen jaren hebben veel onderzoekers deel uitgemaakt van het programma Zorgstelsel \& Sturing bij het Nivel. Sinds 2009 ben ik programmaleider van dit programma en het is ook mede dankzij hen dat ik hier sta. In al die jaren hebben we samen heel veel onderzoek gedaan. Altijd is er de bereidheid om samen te werken, elkaar te helpen en als dat nodig is een tandje bij te zetten. We zien dat binnen het programma bijna als vanzelfsprekend, maar ik denk dat we deze prettige werksfeer met elkaar hebben bereikt en het is een groot goed. Het huidige "team ZOS" wil ik speciaal bedanken: Anne Brabers, Aafke Victoor, Laurens Holst, Madelon Kroneman en Marloes Meijer. Het is erg prettig om met jullie te werken! Bij dat werk kunnen we gebruik maken van een goed geregelde ondersteunende dienst. Een speciaal woord van dank voor jullie, jullie maken het ons een stuk gemakkelijker.

Tot slot wil ik degenen bedanken die het dichtste bij mij staan. 
Mijn ouders wil ik bedanken voor de liefdevolle aandacht, steun en zoveel meer. Een belangrijke bijdrage aan mijn werk leveren jullie al jaren als jullie op onze kinderen passen als Johan en ik samen naar het $\mathrm{EPH}$ - congres vertrekken.

Lieve Johan, ik wil je bedanken voor wie je bent. Zoals jij is er maar één! Je liefde en steun zijn belangrijk voor me en het is fijn dat je naast me staat. Lieve Femke en Mette, wat is het fijn dat jullie er zijn! Jullie brengen veel gezelligheid, humor en relativering. Zo verwezen jullie naar mijn oratie als mijn "spreekbeurt met bitterballen". Nou, die spreekbeurt zit er bijna op en ik denk dat de bitterballen klaar staan.

Ik heb gezegd. 


\section{Literatuur}

Bal, R., Wallenburg I. \& Schuurman J. De zorg moet regionaliseren. Medisch Contact, 22 augustus 2019

Bes, R., Wendel S. \& de Jong J. Het vertrouwensprobleem van zorgverzekeraars, ESB 2012; 97(4647): 676-677

Boonen, L.H.H.M. \& F.T. Schut. Zorgverzekeraars kampen met vertrouwensprobleem, ESB 2009; 94(4572), 678-68

Boudon, R. The Unintended Consequences of Social Action. Londen, Macmillan press, 1982

Brabers, A.E.M. Patient involvement and medical practice variation: can patients be ignored in theories about practice variation? = De betrokkenheid van patiënten en variatie in medisch handelen: kunnen patiënten worden genegeerd in theorieën over praktijkvariatie? Utrecht: NIVEL, 2018.

Graaf N.D. de en Wiertz D. Societal problems as public bads. Routledge, 2019

Jong I. de, Van Twist M. en Chin-A-Fat N., Schuivende perspectieven op sturing in de zorg. Deelrapport 3: Sturingsperspectief. Stichting Onderzoek Systeemvraagstukken Zorgstelsel i.s.m. Nederlandse School voor Openbaar Bestuur. 2016

Delnoij, D.M.J., Groenewegen, P.P., Ros, C.C. Een eigen bijdrage voor de huisarts en de inhoud van de zorg: een studie naar (on)bedoelde gevolgen. Utrecht: NIVEL, 1998

Esch, T.E.M. van, Brabers, A.E.M., Dijk, C. van, Groenewegen, P.P., Jong, J.D. de. Inzicht in zorgmijden: aard, omvang, redenen en achtergrondkenmerken. Utrecht: NIVEL, 2015

Geest. L. van der. Economische effecten van de premiestructuur in de zorg. Den Haag: RVZ, Nyfer, 2008

Groenewegen, P.P., Hansen, J., Jong, J.D. de. Trust in times of health reform. Health Policy 2019; 123(3), 281-287

Groenewegen, P.P., Jong, J.D. de, Kerssens, J.J. Voorkeursaanbieders: selectief contracteren in het nieuwe verzekeringsstelsel. Utrecht: NIVEL, 2002

Hedström P., Swedberg, R. Social mechanisms, an analytical approach to social theory. Cambridge: Cambridge University Press, 1998

Hoefman, R.J., Brabers, A.E.M., Jong, J.D. de. Tabellenboek: vertrouwen in zorgverzekeraars. www.nivel.nl: NIVEL, 2015

Hoefman, R.J., Brabers, A.E.M., Jong, J.D. de. Vertrouwen in zorgverzekeraars hangt samen met opvatting over rol zorgverzekeraars. www.nivel.nl: NIVEL, 2015

Holst, L., Brabers, A.E.M., Jong, J.D. de. $8 \%$ van de verzekerden geeft aan te zijn overgestapt van zorgverzekeraar in 2019. Utrecht: Nivel, 2019 
Lapré, R., F.F.H. Rutten, E. Schut (eds). Algemene Economie van de Gezondheidszorg. Maarssen: Elsevier Gezondheidszorg, 2001

Leys, M. Preferenties en competenties van consumenten. Een quick scan van aandachtspunten en wetenschappelijke inzichten. Den Haag: ZonMw, 2003

Ma, C.A. en M.H. Riordan. Health insurance, moral hazard and managed care. Journal of Economics \& Management Strategy 2002; 11, 81-107.

Maarse H. Markthervorming in de zorg. Maastricht: Universitaire Pers Maastricht. 2011

Meijer, M., Brabers, A., Victoor, A., Jong, J. de. Feitenblad. Negen procent van de mensen ziet af van zorg vanwege de kosten. Er is sprake van een daling in de periode 2016-2019. Utrecht: Nivel, 2020

Pomp M., Mot E., Douven R., Handle with care! Sturingsmodellen voor een doelmatige ouderenzorg. CBS, 2006

Reitsma-van Rooijen M \& Jong J de. Betalen voor SEH schrikt af: ook mensen met acute klachten blijven weg. Medisch Contact 2010;65(29-30):1479-81.

RMO. Rondje voor de publieke zaak. Pleidooi voor de solidaire ervaring. Raad voor Maatschappelijk Ontwikkeling, Den Haag, 2013

Schee, E. van der. Public trust in health care: exploring the mechanisms. = Publiek vertrouwen in de gezondheidszorg: een verkenning van de mechanismen. Utrecht: NIVEL, 2016.

Scott, W.R. Institutions and Organizations. Thousands Oaks: Sage, 2001.

Kemenade, Y. Afname groei gezondheidszorguitgaven. Management Impact, 2019.

Kleef, R.C. van, F.T. Schut, W.P.M.M. van de Ven. Evaluatie zorgstelsel en risicoverevening. Acht jaar na invoering Zorgverzekeringswet: succes verzekerd? Rapport iBMG 2014.01, Onderzoek in opdracht van AmCham, Rotterdam: Erasmus Universiteit, 2014

Varkevisser M. Hand in hand. Op zoek naar de juiste balans tussen marktwerking en overheidsingrijpen in de gezondheidszorg. Oratie, Erasmus universiteit Rotterdam, 2019

Varkevisser, M., N. Polman \& S.A. van der Geest, Zorgverzekeraars moeten patiënten kunnen 'sturen', ESB 2006; 91(4478): 38-40

Ven, W.P.M.M. van de. Het beste zorgstelsel? Afscheidscollege, Erasmus universiteit Rotterdam, 2015

Victoor, A. (How) do patients choose a healthcare provider? $=($ Hoe) kiezen patiënten een zorgaanbieder? Tilburg: Tilburg Universiteit, 2015

Westerhout E, Folmer, K. Co-payment systems in health care between moral hazard and risk reduction. Den Haag: Centraal Plan Bureau, 2007 